Journal of Polytechnic POLITE NAK DERGISI

\section{POLITEKNIK DERGISI}

\section{JOURNAL of POLYTECHNIC}

ISSN: 1302-0900 (PRINT), ISSN: 2147-9429 (ONLINE)

URL: http://dergipark.org.tr/politeknik

\title{
Nokta direnç kaynağı ile birleștirilen titanyum levhaların çekme-makaslama dayanımlarının taguchi metoduyla optimizasyonu
}

\section{Optimization of tensile strength of titanium plates jointed resistance spot welding with taguchi method}

Yazar(lar) (Author(s)): Mehmet Serkan YIDIRIM ${ }^{1}$, Yakup KAYA ${ }^{2}$, Ramazan ÇAKIROĞLU ${ }^{3}$, Behçet GÜLENÇ ${ }^{4}$,Nizamettin KAHRAMAN ${ }^{5}$,Ahmet DURGUTLU ${ }^{6}$

ORCID ${ }^{1}: 0000-0001-6133-6905$

ORCID²: 0000-0002-9951-2844

ORCID ${ }^{3}$ 0000-0002-3120-1599

ORCID ${ }^{4}$ : 0000-0001-8434-8183

ORCID ${ }^{5}$ :0000-0002-7152-3795

ORCID $: 0000-0003-3839-2903$

Bu makaleye şu șekilde atıfta bulunabilirsiniz(To cite to this article): Yıldırım M.S, Kaya Y., Çakıroğlu R., Gülenç B., Kahraman N., Durgutlu N., "Nokta direnç kaynağı ile birleştirilen titanyum levhaların çekmemakaslama dayanımlarının taguchi metoduyla optimizasyonu", Politeknik Dergisi, 22(3): 567-573, (2019). 


\title{
Nokta Direnç Kaynağ ile Birleştirilen Titanyum Levhaların Çekme-Makaslama Dayanımlarının Taguchi Metoduyla Optimizasyonu
}

\author{
Araştırma Makalesi / Research Article \\ Mehmet Serkan YIDIRIM ${ }^{*}$, Yakup KAYA², Ramazan ÇAKIROĞLU ${ }^{1}$, Behçet GÜLENÇ³, \\ Nizamettin KAHRAMAN ${ }^{2}$, Ahmet DURGUTLU ${ }^{3}$ \\ ${ }^{I}$ Gazi Üniversitesi, Teknikbilimler MYO, Makine ve metal teknolojileri Bölümü, Yenimahalle/ANKARA \\ ${ }^{2}$ Karabük Üniversitesi, Teknoloji Fakültesi, İmalat Mühendisliği Bölümü, Karabük Merkez/KARABÜK \\ ${ }^{3}$ Gazi Üniversitesi, Teknoloji Fakültesi Metalurji ve Malzeme. Mühendisliği Bölümü, Yenimahalle/ANKARA
}

(Geliş/Received: 26.02.2018 ; Kabul/Accepted : 27.04.2018)

$\ddot{O} \mathbf{Z}$

\begin{abstract}
$\mathrm{Bu}$ çalışmada; düşük yoğunluk, yüksek dayanım ve mükemmel korozyon direncinden dolayı havacılık, uzay ve kimya endüstrilerinde oldukça yaygın olarak kullanılan ticari saf titanyum(Grade 2) levhalar, nokta direnç kaynak yöntemi ile birleştirilmiştir. Birleştirme işlemlerinde; farklı elektrod kuvveti (3 ve $6 \mathrm{kN})$, kaynak akımı(3,5 ve $7 \mathrm{kA})$ ve kaynak süresi $(10,20$ ve 30 çevrim) kullanılarak, kaynak parametrelerinin çekme-makaslama dayanımında etkisi incelenmiştir. Çekme-makaslama testi sonuçları Taguchi metodunun en büyük-en iyi kontrol karakteristiği ile optimize edilmiştir. Maksimum çekme-makaslama dayanımı için belirlenen optimum test kombinasyonu, A2B3C3 (6kN-7kA-30 çevrim) olarak belirlenmiştir. Çekme-makaslama dayanımı sonuçlarına, kaynak parametrelerinin etkisi varyans analizi (ANOVA) metodu kullanılarak incelenmiş ve en etkin parametrenin \%45.82 ile kaynak akımı olduğu tespit edilmiştir.
\end{abstract}

Anahtar Kelimeler: Nokta direnç kaynağı, çekme dayanımı, ANOVA, Taguchi metodu.

\section{Optimization of Tensile Strength of Titanium Plates Jointed Resistance Spot Welding with Taguchi Method}

\begin{abstract}
In this study, commercial titanium (Grade 2) plates, which are commonly used in aviation, space and chemistry industries because of its low density, high resistance and perfect corrosion resistance, are jointed by using spot resistance welding. In the process, the effect of welding parameters on tensile strength using different electrode strengths ( 3 and $6 \mathrm{kN})$, welding current $(3,5$ and $7 \mathrm{kA})$ and welding time $(10,20$ and 30 cycles). The results of tensile strength test were optimized with the characteristic of maximumbest control of Taguchi method. Optimum test combination for maximum tensile strength was designated as A2B3C $3(6 \mathrm{kN}-7 \mathrm{kA}-$ 30 cycles). Effects of welding parameters on tensile strength results were analyzed with analysis of variant (ANOVA) method and the most effective parameter was determined as welding current with $\% 45.82$.
\end{abstract}

Keywords: Spot resistance welding, tensile strength, ANOVA, Taguchi method.

\section{GİRIȘ (INTRODUCTION)}

Günümüzdeki konstrüksiyonlar iş verimi ve güvenliğini arttırmaya, boyutları ve ağırlığı küçültmeye, aynı zamanda malzeme ve üretim masraflarını azaltmaya yöneliktir.

Konstrüksiyonlardan istenilen bu özelliklerin sağlanmasında malzeme seçimi ve birleştirme yöntemi çok önemlidir [1].

Endüstride kullanılan birleştirme yöntemlerinden en yaygın olanlarından biri de kaynaktır. Son yıllardaki teknolojik gelişmelerle birlikte kaynak teknolojisinde de önemli gelişmeler meydana gelmiştir. Bu gelişen kaynak

*Sorumlu Yazar (Corresponding Author)

e-posta:msy0616@gmail.com yöntemlerinden bir tanesi de nokta direnç kaynak yöntemidir [2].

Nokta direnç kaynağı; iş parçalarından geçen elektrik akımına karşı, iş parçalarının gösterdiği dirençten sağlanan 1sı ve aynı zamanda basıncın tatbiki ile yapılan bir kaynak yöntemidir. Bu kaynak yöntemi, ilave malzeme kullanılmadığından sağladığı hafiflik, yüksek kaynak mukavemeti, estetik oluşu, özel beceri gerekmemesi ve kaynak hızının yüksek oluşu gibi nedenlerle, günümüzde uçak ve otomotiv endüstrisinde ve metal eşya imalatında büyük ölçüde kullanılmaktadır [3-4].

Nokta direnç kaynağı ile endüstriyel uygulamalarda sıkça birleştirilen malzemelerden biri titanyumdur. Titanyum özgül ağırlığı bakımından alüminyumdan yüksek fakat çeliğin \% 60'1 kadardır. Ergime sıcaklığı çelik ve 
alüminyumdan daha yüksektir. Endüstriyel uygulamalarda dayanım ağırlık oranı önemlidir. $\mathrm{Bu}$ açıdan bakıldığında en yüksek dayanımlı titanyum alaşımları yine en yüksek dayanımlı çeliklerle kıyaslanır. $\mathrm{Bu}$ özellikleri ve iyi korozyon direncinden dolayı titanyum alaşımları sanayide sıkça kullanılmaktadır [1,4$6]$.

Nokta direnç kaynak yöntemi ile titanyum levhaların birleştirilmesinde en iyi sonuçları elde etmek için Taguchi metodu ve ortogonal diziler kullanılmaktadır. Taguchi deneyi ile kontrol edilemeyen faktörlere karşı tasarımın duyarlılığı en aza indirgenerek, maliyet ve kalite faktörlerinde optimum bir tolerans aralığının belirlenmesi hedeflenir [7-12].

Lin ve arkadaşları [13],100 x 30 x 0,7 mm boyutlarındaki çelik levhaları nokta direnç kaynak yöntemi ile birleştirilmesinde, Taguchi metodu ve sinir ağları kullanarak optimizasyon sağlamaya çalışmışlardır. Analizler sonucunda, optimum parametre olarak $4 \mathrm{~mm}$ elektrod çap1, 7800A akım değeri, $18 \mathrm{kN}$ elektrod kuvveti ve 8 çevrim kaynak süresi olarak belirlenmiştir. Elde edilen bu kombinasyon değerleri sonrasında toplam \% 15,98 iyileşme sağlanmıştır.

Eşme ve arkadaşları [12], 4 mm kalınlığında AISI 304 paslanmaz çelik sac malzemeleri TIG kaynak yöntemiyle farklı kaynak hızı, kaynak akımı, gaz akış hızı ve ark boyu değerlerinde birleştirmişlerdir. Taguchi modeli ile optimizasyonu için deneyler yapmışlar, analizler sonucunda optimum faktör ve seviye kombinasyonu belirlemişlerdir.

Casalino ve arkadaşları [10], Ti6A14V malzemeleri lazer kaynak yöntemiyle farklı kalınlık, koruyucu gaz türü ve kaynak hızı ile birleştirmişlerdir. Taguchi modeli ile optimizasyonu için deneyler yapmışlar, analizler sonucunda optimum faktör ve seviye kombinasyonunu belirlemişlerdir.

Ayrıca yapılan çalışmalarda istatistiksel bir yöntem olan varyans analizi (ANOVA) yardımıyla hangi kaynak parametresinin mekanik test sonuçlarına ne derece etkili olduğunu gösteren çalışmalar mevcuttur.

Nandagopal ve arkadaşları [14], Pandiarajan ve arkadaşları [15] yapmış oldukları kaynak işlemlerinin mekanik test sonuçlarına varyans analizi yöntemiyle hangi kaynak parametresinin ne derece etkili olduğunu gösteren çalışmalar yapmışlardır.

$\mathrm{Bu}$ çalı̧̧mada, titanyum levhalar nokta direnç kaynak yöntemi ile farklı kaynak parametreleri (elektrod kuvveti, kaynak akımı ve kaynak süresi) kullanılarak birleștirilmiștir. Birleștirme işlemlerinde kullanılan farklı parametrelerin çekme-makaslama dayanımı optimizasyonu, Taguchi metodunun "en büyük-en iyi" kalite kontrol karakteristiği ile çözülmüs ve sonuçlar grafiksel yöntemlerle analiz edilmiştir. Ayrıca çekmemakaslama dayanımı sonuçlarına kullanılan farklı parametrelerden hangisinin daha etkili olduğunu saptamak için ANOVA yöntemi kullanılmıştır.

\section{MALZEME VE METOD (MATERIAL and METHOD)}

Deneysel çalışmalarda kullanılan ticari saf titanyum (Grade 2) levha malzemenin kimyasal bilesimi Çizelge 1 'de verilmiştir.

Çizelge 1. Kullanılan malzemenin kimyasal bileşimi (\% ağırlı) (Chemical composition of the used material)

\begin{tabular}{|c|c|c|c|c|c|c|}
\hline $\begin{array}{c}\text { ASTM } \\
\text { standart1 }\end{array}$ & $\mathbf{N}$ & $\mathbf{C}$ & $\mathbf{H}$ & $\mathbf{F e}$ & $\mathbf{O}$ & $\mathbf{T i}$ \\
\hline Grade 2 & 0,03 & 0,10 & 0,015 & 0,30 & 0,25 & Kalan \\
\hline
\end{tabular}

Birleştirme işlemleri için titanyum malzemeler, Şekil 1 'de gösterilen ölçülerde ve standartlara uygun olarak 100x30x1,5 mm ebatlarında hazırlanmıştır.

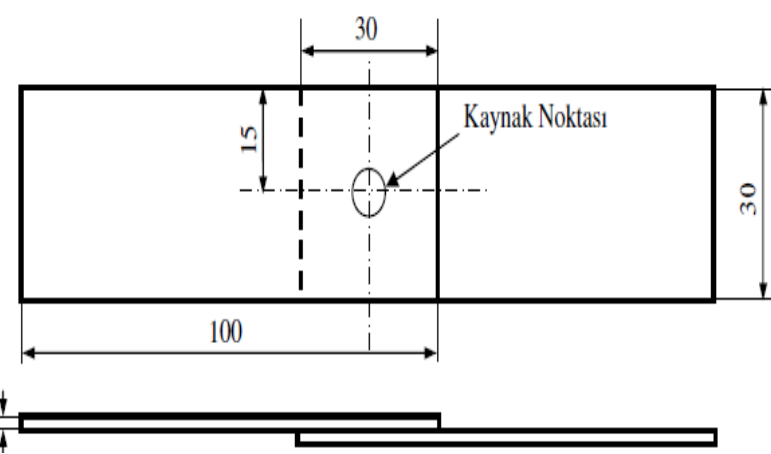

Şekil 1. Nokta direnç kaynak numune ölçüleri (Sample measurements of resistance spot welding)

\subsection{Nokta Direnç Kaynağı (Resistance Spot Welding)}

Titanyum levhaların birleştirilebileceği, kaynak parametrelerini belirlemek için ön deneyler yapılmıştır. Ön çalışmalarda, nokta direnç kaynak işlemi parametrelerinden; elektrod kuvveti, kaynak akımı ve kaynak süresi değiştirilerek titanyum numunelerin birleştirilebildiği kaynak parametreleri belirlenmiştir. Elektrod kuvveti, kaynak akımı ve kaynak süresinin çok düşük ve çok yüksek olduğu ön deneylerde, yetersiz birleştirme ve fazla deformasyondan dolayı kabul edilebilir kaynak çekirdeği sınırları aşılmıştır. Ön deneylerin değerlendirilmesi sonucunda; elektrod kuvveti olarak 3 ve $6 \mathrm{kN}$, kaynak akımı olarak 3, 5 ve 7 kA ve kaynak süresi olarak ise; 10,20 ve 30 çevrimin (1 çevrim $=0,02 \mathrm{sn}$ ) uygun olduğu değerlendirilmiştir.

Deneylerde, titanyum levhaların nokta direnç kaynağı ile birleştirilmelerinde; elektrod kuvveti, kaynak akımı ve kaynak süresi değerlerinin ayarlanabildiği, su soğutmalı ve pnomatik kontrollü nokta direnç kaynağı makinesi kullanılmıştır.

Birleştirilecek malzemeler, Şekil 2'de görülen ve özel olarak hazırlanan kalıbın içerisine yerleştirilerek birleştirme işlemleri gerçekleştirilmiştir. Kaynak süresince elektrod kuvvetinin sabit kalması ve elektrod soğutma suyunun akışı sürekli kontrol edilmiştir. Kaynak işlemi biten numuneler, kalıptan çıkarılarak açık havada 
soğutulmuşlardır. Deneyler esnasında kullanılan kaynak parametreleri Çizelge 2'de verilmiştir.

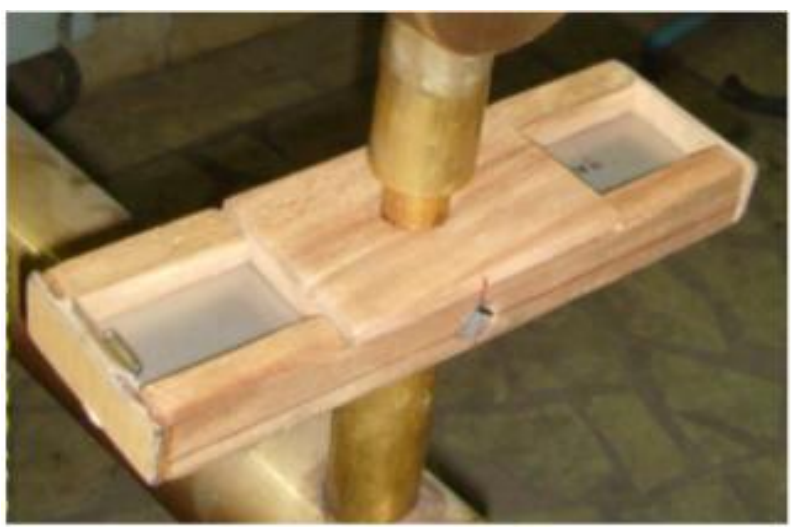

Şekil 2. Kaynak esnasında kullanılan kalıp görüntüsü (The image of the mould used during welding)

Çizelge 2. Kaynak işlemlerinde kullanılan parametreler (Parameters used in welding processes.)

\begin{tabular}{ccccc}
\hline $\begin{array}{c}\text { Elekrod } \\
\text { Kuvveti } \\
(\mathbf{k N})\end{array}$ & $\begin{array}{c}\text { Kaynak } \\
\text { Akımı } \\
(\mathbf{k A})\end{array}$ & $\begin{array}{c}\text { Kaynak } \\
\text { Zamanı } \\
\text { (Çevrim) }\end{array}$ \\
\hline 3 & 3 & 10 & 20 & 30 \\
& 5 & 10 & 20 & 30 \\
6 & 7 & & & \\
\hline
\end{tabular}

\section{2. Çekme-Makaslama Testi (Tensıle Strength Test)}

Nokta direnç kaynak yöntemiyle birleştirilmiş ticari saf (Grade 2) titanyum levhalarda, farklı parametrelerin kaynak dikişinin mekanik özelliklere etkisinin tespiti için Şekil 3'de görülen kaynaklı numuneler hazırlanmıştır. Çekme-makaslama testleri için 5 ton kapasiteli Shimadzu marka çekme testi cihazı kullanılmıştır. Nokta direnç kaynak yöntemi ile 18 farklı parametrede birleştirilmiş kaynaklı numuneler, standartlara (ISO 14273) uygun olarak çekme deney cihazına bağlanmış ve çekmemakaslama testi $2 \mathrm{~mm} / \mathrm{dk}$ çekme hızında gerçekleştirilmiştir. Deneyler sırasında, gerilme değerleri, çekme cihazı üzerindeki proplar ile bilgisayara aktarılarak otomatik olarak kaydedilmiştir. Çekmemakaslama deneyleri, optimum sonuçları elde edebilmek amaciyla, her bir parametreden 3 adet numuneye uygulanmış ve sonuçlar elde edilen bu üç değerin ortalaması alınarak kaydedilmiştir.

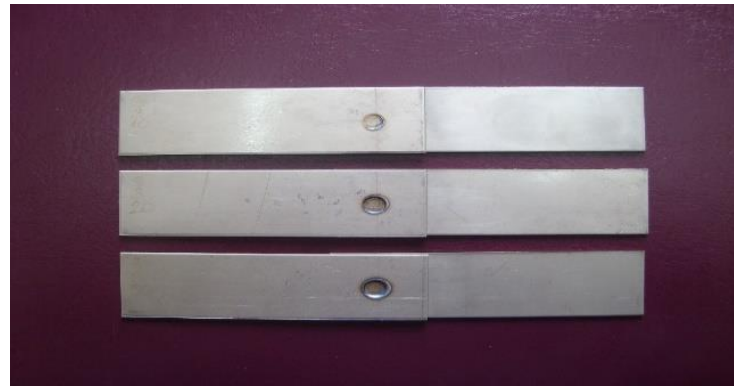

Şekil 3. Çekme-makaslama numuneleri görüntüleri (Images of tensile strength samples)

\section{SONUÇLAR VE TARTIŞMA (RESULTS and DISCUSSION)}

3.1. Çekme-Makaslama Testi Sonuçları (Tensıle Strength Test Results)

3 ve $6 \mathrm{kN}$ elektrod kuvveti, 3, 5 ve 7 kA kaynak akımı ve 10,20 ve 30 çevrim kaynak süresi kullanılarak, nokta direnç kaynak yöntemiyle birleştirilmiş titanyum levhaların mekanik özelliklerinin tespiti için çekmemakaslama test numuneleri hazırlanmıştır. Çekmemakaslama testleri sonucunda elde edilen 3 değerin ortalamaları Çizelge 3'de, verilmiştir.

Çizelge 3. Farklı kaynak parametrelerinden elde edilen çekme-makaslama deneyi sonuçları (Tensile strength test results obtained from different welding parameters)

\begin{tabular}{|c|c|c|c|c|}
\hline $\begin{array}{c}\text { Elektrod } \\
\text { kuvveti } \\
(\mathrm{kN})\end{array}$ & $\begin{array}{c}\text { Kaynak } \\
\text { akımı } \\
(\mathrm{kA})\end{array}$ & $\begin{array}{c}\text { Kaynak } \\
\text { süresi } \\
\text { (Çevrim) }\end{array}$ & $\begin{array}{c}\text { Çekme- } \\
\text { Makaslama } \\
\text { Dayanımı } \\
(\mathrm{N})\end{array}$ & $\begin{array}{c}\text { Deney } \\
\text { numarası }\end{array}$ \\
\hline \multirow{9}{*}{3} & \multirow{3}{*}{3} & 10 & 8.034 & 1 \\
\hline & & 20 & 9.025 & 2 \\
\hline & & 30 & 9.868 & 3 \\
\hline & \multirow{3}{*}{5} & 10 & 8.893 & 4 \\
\hline & & 20 & 10.827 & 5 \\
\hline & & 30 & 11.207 & 6 \\
\hline & \multirow{3}{*}{7} & 10 & 10.810 & 7 \\
\hline & & 20 & 11.537 & 8 \\
\hline & & 30 & 11.703 & 9 \\
\hline \multirow{9}{*}{6} & \multirow{3}{*}{3} & 10 & 9.653 & 10 \\
\hline & & 20 & 10.628 & 11 \\
\hline & & 30 & 10.860 & 12 \\
\hline & \multirow{3}{*}{5} & 10 & 10.727 & 13 \\
\hline & & 20 & 11.818 & 14 \\
\hline & & 30 & 11.934 & 15 \\
\hline & \multirow{3}{*}{7} & 10 & 11.108 & 16 \\
\hline & & 20 & 12.298 & 17 \\
\hline & & 30 & 12.496 & 18 \\
\hline
\end{tabular}


Farklı kaynak parametreleri kullanılarak birleştirilen kaynaklı bağlantılara ait Çizelge 3'te verilen çekmemakaslama testi sonuçları incelendiğinde, en yüksek çekme makaslama dayanımı $12.496 \mathrm{~N}$ ile $6 \mathrm{kN}$ elektrod kuvveti, 7 kA kaynak akımı ve 30 çevrim kaynak süresinde birleştirilen numuneden elde edildiği görülmüştür. En düşük çekme-makaslama dayanımı ise $8.034 \mathrm{~N}$ ile $3 \mathrm{kN}$ elektrod kuvveti, $3 \mathrm{kA}$ kaynak akımı ve 10 çevrim kaynak süresinde elde edilmiştir. Çizelge 3 genel olarak değerlendirildiğinde, kaynak parametrelerinin (elektrod kuvveti, kaynak akımı ve kaynak süresi) artmasıyla birlikte çekme-makaslama değerlerinin de buna bağlı olarak artış gösterdiği görülmektedir.

Çizelge 4. Taguchi $\mathrm{L}_{18}$ deney tasarımına göre deney sonuçları ve $\mathrm{S} / \mathrm{N}$ oranları (Test results according to Taguch $\mathrm{L}_{18}$ test design and $\mathrm{S} / \mathrm{N}$ rates)

\begin{tabular}{|c|c|c|c|c|c|}
\hline \multirow{2}{*}{$\begin{array}{c}\text { Deney } \\
\text { No. }\end{array}$} & \multirow[t]{2}{*}{$\mathbf{A}$} & \multirow[t]{2}{*}{ B } & \multirow[t]{2}{*}{ C } & \multicolumn{2}{|c|}{$\begin{array}{c}\text { Çekme } \\
\text { Makaslama } \\
\text { Dayanımı (N) }\end{array}$} \\
\hline & & & & Ölçülen & $\mathbf{S} / \mathbf{N}$ \\
\hline 1 & 1 & 1 & 1 & 8.034 & 18.0986 \\
\hline 2 & 1 & 1 & 2 & 9.025 & 19.1089 \\
\hline 3 & 1 & 1 & 3 & 9.868 & 19.8846 \\
\hline 4 & 1 & 2 & 1 & 8.893 & 18.9810 \\
\hline 5 & 1 & 2 & 2 & 10.827 & 20.6902 \\
\hline 6 & 1 & 2 & 3 & 11.207 & 20.9898 \\
\hline 7 & 1 & 3 & 1 & 10.810 & 20.6765 \\
\hline 8 & 1 & 3 & 2 & 11.537 & 21.2419 \\
\hline 9 & 1 & 3 & 3 & 11.703 & 21.3659 \\
\hline 10 & 2 & 1 & 1 & 9.653 & 19.6932 \\
\hline 11 & 2 & 1 & 2 & 10.628 & 20.5290 \\
\hline 12 & 2 & 1 & 3 & 10.860 & 20,7166 \\
\hline 13 & 2 & 2 & 1 & 10.727 & 20,6096 \\
\hline 14 & 2 & 2 & 2 & 11.818 & 21,4509 \\
\hline 15 & 2 & 2 & 3 & 11.934 & 21,5357 \\
\hline 16 & 2 & 3 & 1 & 11.108 & 20,9127 \\
\hline 17 & 2 & 3 & 2 & 12.298 & 21,7967 \\
\hline 18 & 2 & 3 & 3 & 12.496 & 21,9354 \\
\hline
\end{tabular}

$\mathrm{S} / \mathrm{N}$ oranı hem ortalama değerleri hem de değişkenliği baz almaktadır. Sinyal faktörü, sistemden elde edilen gerçek değeri ifade ederken gürültü faktörü ise deney tasarımında dikkate alınmayan fakat deney sonucuna etkisi bulunan faktörleri ifade etmektedir. Gürültüye sebep olan kaynaklar, sonuç olarak hedeflenen değerden sapmaya sebep olan bütün değişkenlerdir. $\mathrm{Bu}$ optimizasyon işleminde, Taguchi kayıp fonksiyonu olarak bilinen ve aynı zamanda sinyal/gürültü oranı $(\mathrm{S} / \mathrm{N}$ Sinyal/Noise ratio) fonksiyonu olarak da ifade edilen 3 farklı amaca uygun fonksiyon bulunmaktadır. Buna göre, amacın "en küçük en iyi”, "en büyük en iyi” ve "nominal en iyi”" olmasına göre kullanılan eşitliklerden "en büyük en iyi" (Eş 3.1) kullanılarak S/N oranları hesaplanmış ve eşitlik 3.1'de verilmiştir [16].

\subsection{Sonuçların Taguchi Metodu ile Optimizasyonu (Optimization Of Results With Taguchı Method)}

Taguchi $\mathrm{L}_{18}$ ortogonal düzeni çerçevesinde oluşturulan deney düzeneğine göre yapılan deneyler sonucunda elde edilen çekme-makaslama dayanımı değerlerinin Taguchi metodu yardımıyla deneylerden elde edilen sonuçlar Sinyal/Gürültü (Signal/Noise) oranına dönüştürülmekte ve desibel (dB) olarak ifade edilmektedir. Çekmemakaslama dayanımı ve Sinyal/Gürültü oranları Çizelge 4'de verilmiştir.

$$
S / N=-10 \log \left(\frac{1}{n} \sum_{t=1}^{n} \frac{1}{y_{i}^{2}}\right)
$$

Eşitliklerde;

$$
\begin{aligned}
& \text { yi: Performans yanıtını } \\
& \text { i: gözlem değerini } \\
& \text { n: bir denemedeki test sayısını ifade etmektedir. }
\end{aligned}
$$

Çekme makaslamanın "en büyük en iyi” ye göre $\mathrm{S} / \mathrm{N}$ oranı değişimini gösteren grafik, Sekil 4'te verilmiştir. Sekil 3'de gösterilen $\mathrm{S} / \mathrm{N}$ oranlarının grafiksel gösterimine göre maksimum çekme makaslama için belirlenen optimum deney kombinasyonu A2B3C3 olarak belirlenmiştir. $\mathrm{Bu}$ sonuç artan parametre değerleriyle optimum çekme makaslama değerlerine ulaşıldığını göstermiştir.

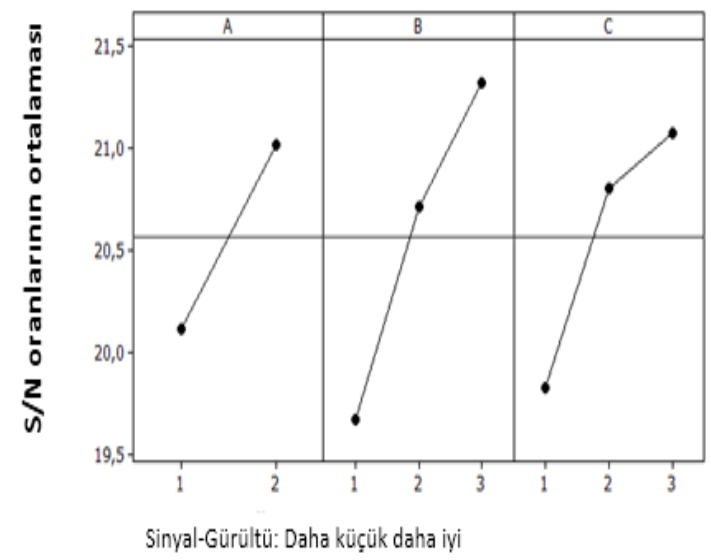

Şekil 4. Çekme makaslama için $\mathrm{S} / \mathrm{N}$ oranı grafiği (The graph of $\mathrm{S} / \mathrm{N}$ ratio for tensile strength)

A. G. Thakur ve arkadaşları [17], nokta direnç kaynaklarıyla birleştirilen kaynaklı parçalarının çekme makaslama dayanımlarının optimum test sonuçlarına ulaşmak için hangi parametre değerlerinin kullanılması gerektiğini bulmak amaciyla Taguchi deneyleri yapmışlardır. Yapılan deneyler sonucunda da, kaynak akım değeri $12 \mathrm{Ka}$, kaynak süresi 16 çevrim, elektrod çap1 $6 \mathrm{~mm}$ ve elektrod kuvveti $3.5 \mathrm{kN}$ değerlerinde optimum sonuçlara ulaşmışlardır. Elde edilen bu parametrelerle yapılan kaynaklarda maksimum çekme makaslama değerleri elde edilmiştir. 
X. Yuan ve arkadaşları [18], nokta direnç kaynaklarıyla birleştirilen kaynak parçalarının çekme makaslama dayanımlarının optimum test sonuçlarına ulaşmak için hangi parametre değerlerinin kullanılması gerektiğini bulmak amacıyla Taguchi deneyleri yapmışlardır. Yapılan deneyler sonucunda da kaynak akım değeri 9kA, kaynak süresi 14 çevirim, ve elektrod kuvveti $2.6 \mathrm{kN}$ değerlerinde optimum sonuçlara ulaşmışlardır. Elde edilen bu parametrelerle yapılan birleştirmelerde maximum çekme makaslama değerlerine ulaşmışlardır. Sonuçlar, kaynak parametrelerinin artmasıyla optimum çekme makaslama sonucuna ulaşıldığını göstermiştir.

\subsection{Anova ile Parametrelerin Değerlendirilmesi} (Evaluation Of Parameters By Anova)

Titanyum levhalar çekme-makaslama test cihazına yerleştirilmiştir. $2 \mathrm{~mm} / \mathrm{dk}$ çekme hızında çekme işlemi gerçekleştirilerek 18 adet deney yapılmış ve bu deneylerin her birinden farklı çekme-makaslama dayanımı değerleri ölçülmüştür. Elde edilen deney sonuçlarına hangi parametrenin ne kadar etki ettiğini bulmak için varyans analizi (ANOVA) kullanılmıştır [19-20]. Çekme-makaslama dayanımı varyans analizi sonuçları Çizelge 5'de verilmiştir

Her faktörün karelerinin toplamının ayrı ayrı hesaplanması sonucu ortaya çıkan değerlerde F'nin en büyük değeri çekme makaslamayı etkileyen en önemli faktördür. Çizelge 5' te görüleceği üzere, \%45.82 ile en

\subsection{Doğrulama Deneyleri Ve Sonuçları (Verıfıcatıon} Experıments And Results)

Taguchi metoduna göre, optimal sonuçları verecek parametrelerin tahmininden sonra, optimizasyonda son aşama olarak doğrulama deneyleri yapılmakta ve yapılan optimizasyonun doğruluğu kontrol edilmektedir. Önceden tespit edilen çekme-makaslama için "A2B3C3" parametreleri kullanılarak, üç adet kontrol deneyleri sonucunda elde edilen deney sonuçlarının ortalaması alınarak sonuçların güvenilirliği irdelenmiştir. Buna göre en iyi çekme makaslama değerlerinin elde edilmesinde, optimize edilmiş çekme-makaslama parametreleri Çizelge 6' da verilmiştir.

Çizelge 6. Çekme makaslama için optimal seviyeler (Optimal levels for tensile strength)

\section{Başlangıç \\ dayanım \\ parametreleri Tahmini Deneysel}

\begin{tabular}{cccc}
\hline Seviye & A2B2C2 & A2B3C3 & A2B3C3 \\
$\begin{array}{c}\text { Çekme- } \\
\text { makaslama }\end{array}$ & 11.818 & 12.7918 & 12.713 \\
$\begin{array}{c}\text { S/N oranı } \\
(\mathrm{dB})\end{array}$ & 21.4508 & 22.2776 & 22.0849 \\
$\begin{array}{c}\text { İyileștirme } \\
\text { oranı } \mathrm{S} / \mathrm{N}\end{array}$ & $0.6341 \mathrm{~dB}(2,95 \%)$ & \\
\hline
\end{tabular}

Çizelge 5. Çekme makaslama değerlerine göre ANOVA sonuçları (ANOVA results according to tensile strength values)

\begin{tabular}{ccccccc}
\hline Kaynak & SD & KT & KO & F & P & PCR (\%) \\
\hline Elektrod kuvveti & 1 & 5,139 & 5,1392 & 45,94 & 0 & 19.58 \\
Kaynak akımı & 2 & 11,986 & 5,9928 & 53,58 & 0 & 45.82 \\
Kaynak süresi & 2 & 7,204 & 3,6018 & 32,2 & 0 & 27.19 \\
Hata & 12 & 1,342 & 0,1119 & & 7.41 \\
Toplam & 8 & 167.459 & & & 100 \\
\hline
\end{tabular}

fazla etkileyen faktörün kaynak akımı, ikinci etkili faktörün \%27.19 ile kaynak süresi ve en az etkili olan faktörün ise \%19.58 ile elektrod kuvveti olduğu belirlenmiştir.

Shaik Shafee ve arkadaşlarının [21] yapmış oldukları çalışmalarda, ANOVA ile yapılan analizlerin sonucunda nokta direnç kaynaklarıyla birleştirilen kaynaklı parçaların çekme makaslama dayanımlarına en çok etkisi olan kaynak parametresini \%72.79 ile kaynak akımı olarak bulmuşlardır. Bunu sırasıyla \%22.26 ile kaynak süresi ve son olarak ta $\% 4.95$ ila elektrod kuvveti olarak izlemiştir.

A. K. PANDEY ve arkadaşlarının [22] yapmış oldukları çalışmalarda, ANOVA ile yapılan analizlerin sonucunda nokta direnç kaynaklarıyla birleştirilen kaynaklı parçaların çekme makaslama dayanımlarına en çok etkisi olan kaynak parametresinin \%61 ile kaynak akımı olduğu tespit edilmiştir. Bunu sırasıyla \%28.7 ile kaynak süresi ve son olarakta \%4.3 ila elektrod kuvveti takip etmiştir.
Taguchi optimizasyonu sonucunda belirlenen A2B3C3 kaynak parametrelerini kullanılarak 3 adet doğrulama deneyi yapılmış ve optimizasyonun başarısı irdelenmiştir. Doğrulama deneyleri sonunda elde edilen $\begin{array}{llll}\text { çekme-makaslama dayanımı } 12.713 \mathrm{~N} \text { olarak } & \end{array}$ ölçülmüştür. Böylelikle, başlangıç deneylerde elde edilen çekme-makaslama dayanımı değerine göre $(11.818 \mathrm{~N})$ optimizasyon sonunda \%2.95 oranında iyileştirme sağlanmıştır. Taguchi metodunun yapılan çalışmada başarılı bir şekilde uygulanabildiği görülmüştür.

S.V. Fanse ve arkadaşları [23], 250 × 28 × 1,2 mm boyutlarındaki çelik levhaları nokta direnç kaynak yöntemi ile birleştirilmesinde, Taguchi metodu ve yapay sinir ağları kullanarak optimizasyon sağlamaya çalışmışlardır. Analizler sonucunda, optimum parametre olarak $11 \mathrm{kA}$ akım değeri, $0.78 \mathrm{kN}$ elektrod kuvveti ve 5 çevrim kaynak süresi olarak belirlenmiştir. Elde edilen bu kombinasyon değerleri sonrasında yaklaşık \% 10 iyileşme sağlanmıştır. 
M. Raut ve V. Achwal [24], 1500 × 25 × $0.8 \mathrm{~mm}$ boyutlarındaki orta karbonlu çelik levhaların nokta direnç kaynak yöntemi ile birleştirilmesinde, Taguchi metodunu kullanarak optimizasyon sağlamaya çalışmışlardır. Yaptıkları çalışmalar sonucunda, optimum parametre olarak $8.4 \mathrm{kA}$ akım değeri, $269.2 \mathrm{~N}$ elektrod kuvveti ve 15 çevrim kaynak süresini tespit etmişlerdir. Elde edilen bu kombinasyon değerleri sonrasında yaklaşık \% 25 iyileşme sağlanmıştır.

\section{SONUCLAR (CONCLUSION)}

Nokta direnç kaynağı ile birleştirilen 1,5 $\mathrm{mm}$ kalınlığındaki Titanyum levhaların çekme-makaslama dayanımlarının Taguchi metoduyla optimizasyonu konulu bu çalışmada, yapılmış olan deneyler neticesinde aşağıda verilmiş olan sonuçlar elde edilmiştir.

Taguchi metodu kullanılarak yapılan optimizasyon sonucunda maksimum çekme-makaslama dayanımı değeri için optimum parametreler, elektrod kuvveti $6 \mathrm{kN}$, kaynak akımı $7 \mathrm{kA}$ ve kaynak süresi 30 çevrim (A2B3C3) olarak belirlenmiştir.

Belirlenen kaynak parametreleri kullanılarak ulaşılan maksimum çekme-makaslama dayanımı değeri $12,713 \mathrm{~N}$ olarak bulunmuştur.

Elde edilen optimum kaynak parametreleri kullanılarak yapılan doğrulama deney sonuçlarına göre çekmemakaslama dayanımında $\% 2,95$ oranında iyileşme sağlanmıştır.

Deney sonuçlarına uygulanan varyans analizi'ne (ANOVA) göre, değişkenlerin çekme-makaslama dayanımı değerleri üzerindeki en etkin parametrenin \%5,82 ile kaynak akımı olduğu tespit edilirken, ikinci en etkili parametrenin \%27,19 ile kaynak süresi ve en az etkili parametrenin ise \%19,58 ile elektrod kuvvetinin olduğu belirlenmiştir.

Yapılan deneyler sonucunda kaynaklı bağlantıların çekme-makaslama dayanımlarını arttırdığı ya da azalttığ için kaynak parametrelerinin önemli olduğu görülmüştür. $\mathrm{Bu}$ nedenle uygun parametre kombinasyonlarının nokta direnç kaynaklarının maksimum çekme-makaslama dayanımı için gerekli olduğu söylenebilir.

\section{KAYNAKLAR (REFERENCES)}

[1] Kaya Y., "Titanyum sacların nokta direnç kaynağı ile kaynaklana bilirliğinin araştırılması”, Yüksek Lisans Tezi, Karabük Üniversitesi Fen Bilimleri Enstitüsü, (2010).

[2] Gültekin N., “Kaynak teknĭği ’, Yıldız Üniversitesi Yayınları, İstanbul, 1-27,(1985).

[3] Eryürek B., "Elektrik direnç nokta kaynağında temas direncinin etüdü”, Doktora Tezi, İstanbul Teknik Üniversitesi Fen Bilimleri Enstitüsü, İstanbul, 10-46 (1976).

[4] Agwan V.S., "Resistance welding reliable technology for productivity", Tool and Alloy Steels, 243-247, (1989).

[5] Kahraman N., "Titanyum levhaların patlamalı kaynak yöntemi ile farklı metallerle birleştirilmesi ve arayüzey özelliklerinin incelenmesi’, Doktora Tezi, Gazi Üniversitesi Fen Bilimleri Enstitüsü, Ankara, 1-23, (2003).

[6] Dogan İ., "Titanyum malzemelerin (kalite 265.2) TIG kaynak yöntemi ile kaynaklanabilirliğinin incelenmesi', Yüksek Lisans Tezi, Gazi Üniversitesi Fen Bilimleri Enstitüsü, Ankara, 1-4, (2002).

[7] Şirvancı M., "Kalite için deney tasarımı yaklaşımı, taguchi yaklașımı", Wisconsin Üniversitesi ișletme Fakültesi, ABD, (1997).

[8] Caniyilmaz E., Kutay F., "Taguchi Metodunda Varyans Analizine Alternatif Bir Yaklaşım”, Gazi Üniv. Müh. Mim. Fak. Dergisi, 18(3): 51-63, (2003).

[9] Anawa E.M., and Olabi A.G., "Using Taguchi Method To Optimize Welding Pool of Dissimilar Laser-Welded Components", Optics \& Laser Technology. 40(2): 379 388, (2008).

[10] Casalino G., Curcio F. and Minutolo F. M. C., "Investigation on Ti6A14V laser welding using statistical and Taguchi approaches", Journal of Materials Processing Technology, 167(2-3): 422-428, (2005).

[11] Lin H.L. and Chou C.P., " Optimisation of The GTA Welding Process Using The Taguchi Method and a Neural Network', Science and Technology of Welding \& Joining, 11(1): 120 - 128, (2006).

[12] Eşme, U., Bayramoğlu , M., Geren N., Serin H., "TİG kaynağında kaynak dayanımının taguchi metoduyla optimizasyonu ", Tasarım İmalat Analiz Kongresi, Balıkesir.(2006).

[13] Lin, H.L., Chou, T., Chou, C.P., "Optimization of Resistance Spot Welding Process Using Taguchi Method and a Neural Network', Experimental Techniques, 31(5): $30-36$, (2007)

[14] Nandagopal K., Kailasanathan C., "Analysis of mechanical properties and optimization of gas tungsten Arc welding (GTAW) parameters on dissimilar metal titanium $(6 \mathrm{Al} 4 \mathrm{~V})$ and aluminium 7075 by Taguchi and ANOVA techniques", Journal of Alloys and Compounds, 682: 503-516, (2016).

[15] Pandiarajan, S., et al., "Interfacial microstructure and optimization of friction welding by Taguchi and ANOVA method on SA 213 tube to SA 387 tube plate without backing block using an external tool",Journal of Alloys and Compounds, 654: 534-545, (2016).

[16] Çakıroğlu R., Acır A., "A12014 malzemesinin delinmesinde takım talaş ara yüzey sıcaklıkları ve kesme kuvvetinin taguchi metodu ile optimizasyonu ", Makine Teknolojileri Elektronik Dergisi, 10(2): 73-86, (2013).

[17] Thakur A.G., RaoL T.E., Mukhedkar M.S., Nandedkar V.M., "Application of taguchi method for resistance spot welding of galvanized steel', ARPN Journal of Engineering and Applied Sciences, 5: 11, (2010).

[18] Yuan X., Li C., Chen J., Li X, Liang X., Pan X., "Resistance spot welding of dissimilar DP600 and DC54D steels", Journal of Materials Processing Technology, 239: 31-41, (2017).

[19] R. Çakıroğlu., and A. Acır., "Optimization of cutting parameters on drill bit temperature in drilling by Taguchi method", Measurement, 9(46): 3525-3531, (2013).

[20] Yağmur S., et al., "AISI 1050 çeliğinin delinmesinde kesme kuvvetlerinin taguchi metodu ile optimizasyonu", 
Gazi Üniversitesi Fen Bilimleri Dergisi Part C: Tasarım ve Teknoloji, 5(2): 241-246, (2017).

[21] Shafe S., Naikb B.B., Sammaiah K., "Resistance Spot Weld Quality Characteristics Improvement By Taguchi Method', Materials Today, 2: 2595 - 2604, ( 2015 ).

[22] Pandey A.K.,, Khan M.I., Moeed K.M., "Optimization of resistance spot welding parameters using taguchi method ", International Journal of Engineering Science and Technology, 5(2): (2013).
[23] Fanse S.V., Deshmukh D.D., Niphade D.V., "Experimental investigation and optimization of spot welding process parameters for maximum tensile strength", International Journal of Advance Research in Science and Engineering, 978-93-86171-05-4, (2016).

[24] M. Raut., V. Achwal., "Optimization of spot welding process parameters for maximum tensile strength", International Journal of Mechanical Engineering and Robotics Research, 3(4): 2278 - 0149, (2014) 